\title{
ANALISIS KEANDALAN PERAWATAN SUB-SISTEM ELEKTRIK, INSTRUMENTASI DAN KONTROL RSG-GAS
}

\author{
Mike Susmikanti ${ }^{1}$, Entin Hartini ${ }^{1}$, Aep Saepudin ${ }^{2}$, Purwadi ${ }^{2}$ \\ ${ }^{1}$ Pusat Teknologi Keselamatan Reaktor Nuklir, BATAN, Tangerang Selatan, 15310 \\ ${ }^{2}$ Pusat Reaktor Serba Guna, BATAN, Tangerang Selatan, 15310 \\ mike@batan.go.id
}

\begin{abstract}
ABSTRAK
ANALISIS KEANDALAN PERAWATAN SUB-SISTEM ELEKTRIK, INSTRUMENTASI DAN KONTROL RSG-GAS. Analisis keandalan sub-sistem merupakan faktor utama pada manajemen penuaan RSG-GAS. Laporan Operasi RSG-GAS belum digunakan secara optimal untuk kajian keandalan khususnya sub-sistem elektrik, instrumentasi, dan kontrol. Sistem basis data RSGGAS belum digunakan untuk membantu pencarian data kegagalan dan perawatan sub-sistem. Demikian pula, analisis keandalan belum dilakukan untuk memantau kinerja sub-sistem elektrik, instrumentasi, dan kontrol. Tujuan penelitian ini adalah melakukan analisis keandalan pada subsistem elektrik, instrumentasi dan kontrol. Kegiatan penelitian meliputi pencarian data dan informasi melalui sistem basis data, khususnya kegagalan untuk sub-sistem elektrik, instrumentasi, dan kontrol pada Teras nomor 53 sampai 88 pada rentang tahun 2005-2015. Dilakukan perhitungan frekuensi kegagalan pada sub-sistem elektrik, instrumentasi, dan kontrol, kemudian dilakukan uji kesuaian untuk bentuk sebaran data waktu kegagalan serta perhitungan parameter rata-rata waktu kegagalan. Hasil analisis dilakukan untuk memperoleh sebaran yang sesuai untuk masing-masing sub-sistem elektrik, instrumentasi, dan kontrol yang mengalami kegagalan dalam kurun waktu tersebut. Berdasarkan jenis sebaran yang sesuai diperoleh parameter rata-rata waktu kegagalan sub-sistem. Dilakukan perbandingan rata-rata waktu kegagalan terhadap interval waktu perawatan sub-sistem. Apabila rata-rata waktu kegagalan lebih lama dari interval waktu perawatan yang telah ditetapkan, maka perawatan untuk sub-sistem elektrik, instrumentasi, dan kontrol relatif baik. Melalui analisis keandalan perawatan, diperoleh bahwa sub-sistem elektrik, instrumentasi. dan kontrol relatif masih dalam kondisi baik.
\end{abstract}

Kata kunci: Manajemen Penuaan, Analisis Keandalan, Perawatan dan Kegagalan, Sub-sistem Elektrik, Sub-sistem Instrumentasi dan Kontrol, RSG-GAS

ABSTRACT
RELIABILITY ANALYSIS OF MAINTENANCE FOR ELECTRICAL,
INSTRUMENTATION, AND CONTROL OF RSG-GAS. Reliability analysis is a major factor
in the aging management of RSG-GAS. The RSG-GAS Operational Report has not been used
optimally for the reliability study, especially the electrical, instrumentation, and control sub-
systems. The RSG-GAS database system has not been used to assist in the search for data sub-
system failure and maintenance data. Similarly, reliability analysis has not been carried out to
monitor the performance of the electrical, instrumentation, and control sub-systems. The purpose
of this study is to analyze the reliability of the electrical, instrumentation, and control sub-systems.
This research activity includes searching for data and information through a database system,
specifically the failure for the electrical, instrumentation, and control sub-systems on Core
numbers 53 to 88 during year 2005-2015 period. The frequency of failure is calculated for
electrical sub-systems, instrumentation, and control. Next, the distribution of the fittest is
performed for the failure time data. The average failure time parameter is calculated. The results
of the analysis were carried out to obtain the appropriate distribution for each electrical,
instrumentation, and control sub-system that experienced a failure in the aforementioned period.
Through match testing, the appropriate type of distribution for each sub-system failure is


obtained. Based on the appropriate type of distribution obtained the average parameters of the failure time of the sub-system. The average failure time of the sub-system is compared with the interval of maintenance period. If the average failure time is longer than the prescribed maintenance time interval, the maintenance for the electrical, instrumentation, and control subsystems is said to be relatively good. According to this analysis, the electrical, instrumentation, and control sub-systems are still relatively in good condition.

Keywords: Aging Management, Reliability Analysis, maintenance and Failure, Electrical Subsystem, Instrumentation, and Control Sub-system, RSG-GAS 


\section{PENDAHULUAN}

Analisis keandalan sub-sistem sangat diperlukan pada manajemen penuaan RSGGAS. Sementara, sistem basis data yang berkaitan dengan struktur sistem dan komponen RSG-GAS belum digunakan secara optimal. Sistem basis data dapat membantu pencarian data dan informasi secara cepat. Informasi ini dapat digunakan untuk mengkaji keandalan masing-masing sistem dan sub-sistem. Kelompok sistem elektrik dan instrumentasi RSG-GAS meliputi sub-sistem electric power supply, instrument control cabinet, dan instrument control board. Analisis keandalan dapat dilakukan diantaranya melalui informasi data kegagalan.

Saat ini, telah dilakukan pengembangan sub-sistem basis data untuk analisis keandalan sub-sistem RSG-GAS berbasis WEB ${ }^{[1]}$. Disamping itu, telah dibuat purwarupa perangkat lunak untuk pengoperasian parameter RSG-GAS berbasis $\mathrm{WEB}^{[2]}$. Telah dilakukan pula analisis keandalan untuk sistem purifikasi KBE01 dan sub-sistem lapisan air hangat KBE02 ${ }^{[3]}$. Sistem elektrik dan instrumentasi merupakan sistem yang selalu berada dalam pemantauan perawatan sesuai dengan kurun waktu yang telah ditetapkan oleh unit jaminan mutu ${ }^{[4]}$. Waktu kegagalan dan interval perawatan masing-masing sistem dan komponen dalam Laporan operasi reaktor RSG-GAS dapat digunakan untuk analisis keandalan ${ }^{[5]}$. Demikian pula, telah dibuat laporan operasi reaktor RSG-GAS untuk teras 53 sampai dengan teras 88 , khususnya untuk perawatan sistem RSG-GAS ${ }^{[6]}$. Hasil evaluasi masa operasi PLTN termasuk RSG-GAS telah dikaji oleh IAEA termasuk keandalan sistem dan komponennya ${ }^{[7]}$. Klasifikasi keamanan struktur dan sistem telah dikaji untuk reaktor riset tipe kolam ${ }^{[8]}$.

Di sisi lain, penelitian tentang uji kesesuaian untuk suatu sebaran data yang mengikuti Sebaran Weibull telah dilakukan [9]. Demikian pula, sebaran sumber data yang ekstrim telah dikaji dengan metode estimasi ${ }^{[10]}$. Pemodelan sebaran data telah dilakukan dengan penerapan empat distribusi kemungkinan $^{[11]}$. Berikutnya. telah dilakukan perhitungan pendekatan sebaran robust dengan metoda pendekatan peluang ${ }^{[12]}$.

Analisis keandalan untuk manajemen penuaan RSG-GAS khususnya manajemen perawatan sangat diperlukan dan belum sepenuhnya dilakukan untuk memantau penggunaan sistem RSG-GAS secara selamat. Sistem basis data yang berisi informasi yang diperlukan belum digunakan secara optimal untuk beberapa kajian keandalan sistem yang digunakan di RSGGAS, khususnya elektrik dan instrumentasi.

Penelitian ini bertujuan melakukan analisis keandalan dalam kaitannya dengan kajian waktu kegagalan sistem dalam kurun waktu tertentu khususnya untuk sub-sistem 
yang termasuk dalam kelompok elektrik, instrumentasi, dan kontrol.

Kegiatan penelitian ini meliputi pencarian data kegagalan, secara khusus sistem instrumentasi dan elektrik, melalui sistem basis data. Berikutnya, dilakukan perhitungan frekuensi masing masing subsistem pada sistem instrumentasi dan elektrik seluruh teras serta dibuat distribusi frekuensi dalam kurun waktu tahun 2005-2015 pada teras 53-88. Dilakukan uji kesesuaian sebaran untuk waktu kegagalan kelompok sub-sistem elektrik dan instrumentasi menggunakan Minitab dan perhitungan parameter rata-rata waktu kegagalan yang akan dibandingkan dengan interval waktu perawatan sub-sistem yang telah ditentukan. Apabila waktu kegagalan sub-sistem lebih lama dari interval waktu perawatan yang ditetapkan, maka subsistem masih dalam keadaan baik atau efisien.

\section{TEORI}

Pada analisis keandalan sub-sistem, waktu kegagalan sub-sistem merupakan faktor yang sangat signifikan. Waktu kegagalan (Time To Failure: TTF) adalah waktu perkiraan antara waktu kegagalan subsistem sebelumnya $T_{i-1}$ dengan waktu kegagalan sub-sistem berikutnya $T_{i}$ yang dinyatakan dalam persamaan (1) ${ }^{[3]}$.

$$
T T F=T_{i}-T_{i-1}
$$

dengan penjelasan,
$T_{i}$ : Waktu pada saat kegagalan (hari)

$T_{i-1}$ : Waktu kegagalan sebelumnya (hari)

Sebaran data waktu kegagalan dapat merupakan sebaran yang kontinyu atau berkesinambungan, diantaranya meliputi sebaran Eksponensial, Weibul, Normal, dan Lognormal [11].

Sebaran Eksponensial mempunyai fungsi kepekatan peluang yang dinyatakan dalam persamaan (2),

$$
f(x)=\lambda \exp (-\lambda x), \mathrm{x}>0
$$

Nilai rata-rata untuk sebaran eksponensial dinyatakan dalam persamaan (3),

$$
E(x)=\frac{1}{\lambda}
$$

dengan $\lambda$ adalah nilai rata-rata

Fungsi peluang sebaran Weibull dinyatakan dalam persamaan (4),

$$
f(x)=\frac{\beta}{\eta}\left(\frac{x}{\eta}\right)^{\beta-1} \exp \left[-\left(\frac{x}{\eta}\right)^{\beta}\right], \mathrm{x}>0, \eta, \beta \geq 0
$$

Nilai rata-rata $\mathrm{E}(\mathrm{x})$ sebaran Weibull dinyatakan dalam persamaan (5),

$$
E(x)=\eta x \Gamma\left(\frac{1}{\beta}+1\right]
$$

dengan $\beta$ adalah Shape dan $\eta$ merupakan nilai rata-rata.

Fungsi peluang sebaran normal dinyatakan dalam persamaan (6),

$$
\left.f(x)=\frac{1}{\sigma \sqrt{2 \pi}} \exp \left(-\frac{1}{2}\right)\left(\frac{x-\mu}{\sigma}\right)^{2}\right), \mathrm{x}>0(6)
$$

Persamaan (7) menyatakan rata-rata sebaran normal,

$$
E(x)=\mu
$$


Fungsi peluang sebaran lognormal dinyatakan dalam persamaan (8)

$$
\left.f(x)=\frac{1}{x \sigma \sqrt{2 \pi}} \exp \left(-\frac{1}{2}\right)\left(\frac{\ln x-\mu}{\sigma}\right)^{2}\right)
$$

Nilai rata-rata sebaran lognormal dinyatakan dalam persamaan (9).

$$
E(x)=\mu
$$

dengan $\mu$ adalah nilai rata-rata dan $\sigma$ adalah simpangan baku.

\section{Statistik Anderson-Darling} adalah ukuran seberapa jauh plot titik berada tepat dari garis dalam plot probabilitas. Statistik adalah jarak kuadrat dari plot titik ke tepat garis dengan bobot yang lebih besar di ekor sebaran. Statistik Anderson-Darling dinyatakan pada persamaan (10). Nilai Anderson-Darling yang lebih kecil menunjukkan bahwa distribusi sesuai dengan data adalah lebih baik ${ }^{[3]}$.

$$
A D=-n-\frac{1}{n} \sum_{i=1}(2 i-1)\left[\ln F\left(X_{i}\right)+\ln \left(1-F\left(X_{n-i+1}\right)\right)\right]
$$

dengan $\mathrm{n}$ adalah ukuran sampel, $\mathrm{i}$ adalah sampel ke-i untuk data yang telah diurutkan dalam urutan menaik, dan F(X) adalah Fungsi distribusi kumulatif untuk distribusi yang sesuai.

\section{METODOLOGI}

Langkah pertama untuk melakukan analis keandalan adalah pengumpulan data kegagalan untuk sistem elektrik, insrumentasi, dan kontrol pada kurun waktu tahun 2005 sampai 2015 pada Teras nomor
53-88) menggunakan sistem basis data open source LOCALHOST XAMPP. Program SQL dibuat untuk pencarian data kegagalan sub-sistem instrumentasi dan elektrik serta pembuatan informasi. Berikutnya, dilakukan perhitungan dan pembuatan sebaran frekuensi sub-sistem instrumentasi dan elektrik yang mengalami kegagalan untuk seluruh teras 53-88. Uji kesesuaian terbaik dilakukan untuk sebaran data sub-sistem instrumentasi dan elektrik yang mengalami kegagalan dengan jumlah frekuensi minimal 4 dalam kurun waktu tahun 2005-2015. Distribution overview plot digunakan dalam analisis keandalan untuk menguji sebaran data mengikuti sebaran tertentu. Sebaran data menggunakan data selisih waktu kegagalan antara waktu kegagalan sebelumnya (n-1) dengan waktu kegagalan berikutnya (n) yang dinyatakan dalam nilai TTF. Analisis sebaran data dipilih yang mendekati salah satu dari empat sebaran yaitu Eksponensial, Weilbul, Lognormal, dan Normal. Digunakan uji Anderson-Darling untuk menguji kesesuaian beberapa sebaran data ${ }^{[13]}$. Uji kesesuaian sebaran mengambil nilai Anderson-Darling terkecil yang kemudian dilakukan perhitungan nilai rata-rata waktu kegagalan untuk sebaran yang sesuai.

\section{HASIL DAN PEMBAHASAN}

Hasil pencarian informasi sub-sistem yang mengalami kegagalan dilakukan menggunakan sistem basis data. Diperoleh 
frekuensi sub-sistem instrumentasi dan elektrik yang mengalami kegagalan. Data frekuensi tersebut ditampilkan pada Tabel 1.

Tabel 1. Frekuensi kegagalan sub-sistem elektrik, instrumentasi dan kontrol Teras 53-88

\begin{tabular}{|c|c|c|c|}
\hline $\begin{array}{c}\text { Sub- } \\
\text { Sistem }\end{array}$ & Deskripsi & $\begin{array}{c}\text { Interval } \\
\text { Perawatan }\end{array}$ & $\begin{array}{l}\text { Frekuensi } \\
\text { kegagalan }\end{array}$ \\
\hline BRV10 & $\begin{array}{c}\text { Emergency } \\
\text { Diesel } \\
\text { Aggregates }\end{array}$ & 6 bulan & 11 \\
\hline BRV20 & $\begin{array}{c}\text { Emergency } \\
\text { Diesel } \\
\text { Aggregates }\end{array}$ & 6 bulan & 11 \\
\hline BRV30 & $\begin{array}{c}\text { Emergency } \\
\text { Diesel } \\
\text { Aggregates }\end{array}$ & 6 bulan & 9 \\
\hline $\mathrm{BNC} 01$ & $\begin{array}{c}\text { Emergency } \\
\text { Distribution } \\
\text { board }\end{array}$ & 6 bulan & 4 \\
\hline CRB01 & $\begin{array}{l}\text { Cabinets for } \\
\text { Signal Cond. }\end{array}$ & 6 bulan & 9 \\
\hline CRB03 & $\begin{array}{l}\text { Cabinets for } \\
\text { Signal Cond. }\end{array}$ & 6 bulan & 4 \\
\hline
\end{tabular}

Sistem elektrik, instrumentasi, dan kontrol terdiri dari electric power supply, instrument control cabinet, dan instrument control board. Sebaran data dapat dianalisis jika frekuensi waktu kegagalan minimal 4. Sub-sistem electric power supply yang mengalami kegagalan dengan frekuensi minimal 4 ialah sub-sistem BRV10, BRV20, BRV30, dan BNC01, masing masing sebanyak 11, 11, 9, dan 4. Sedangkan sub-sistem yang termasuk instrument control cabinet yang mengalami kegagalan dengan jumlah frekuensi minimal 4 ialah sub-sistem CRB01 sebanyak 9 dan CRB03 sebanyak 4.

Distribusi frekuensi untuk kegagalan sub sistem elektrik, instrumentasi dan kontrol Teras 53-88 dinyatakan pada Gambar 1.

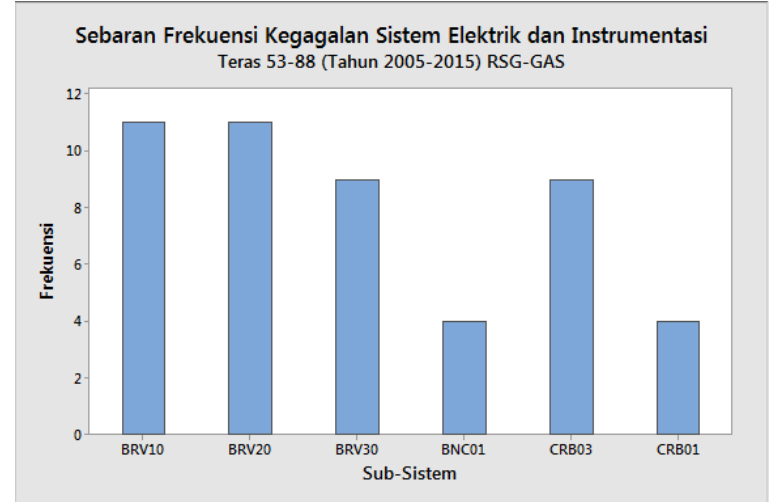

Gambar 1. Distribusi frekuensi kegagalan subsistem elektrik, instrumentasi dan kontrol Teras 53-88

Selisih waktu kegagalan antara kegagalan sebelumnya dengan berikutnya yang dinyatakan dalam nilai TTF (sesuai Pers. 1) untuk sub-sistem BRV10 dinyatakan pada Tabel 2.

Tabel 2. Waktu kegagalan sub-sistem electric power supply BRV10 Teras 53-88

\begin{tabular}{|c|c|c|}
\hline $\begin{array}{c}\text { Teras } \\
\text { Nomor }\end{array}$ & Waktu Kegagalan & TTF \\
\hline 53 & $2005-05-26$ & 0 \\
\hline 58 & $2006-08-02$ & 433 \\
\hline 58 & $2006-08-08$ & 6 \\
\hline 68 & $2008-08-13$ & 736 \\
\hline 69 & $2009-02-12$ & 183 \\
\hline 73 & $2010-11-24$ & 650 \\
\hline 78 & $2012-05-08$ & 531 \\
\hline 85 & $2014-02-07$ & 640 \\
\hline 85 & $2014-02-26$ & 19 \\
\hline 85 & $2014-05-15$ & 78 \\
\hline 85 & $2014-05-20$ & 5 \\
\hline
\end{tabular}




\begin{tabular}{|c|c|c|}
\hline $\begin{array}{c}\text { Teras } \\
\text { Nomor }\end{array}$ & $\begin{array}{c}\text { Waktu } \\
\text { Kegagalan }\end{array}$ & $\begin{array}{c}\text { TTF } \\
\text { (hari) }\end{array}$ \\
\hline 59 & $14 / 12 / 2006$ & 0 \\
\hline 81 & $22 / 01 / 2013$ & 2231 \\
\hline 85 & $20 / 01 / 2014$ & 363 \\
\hline 86 & $07 / 01 / 2015$ & 352 \\
\hline
\end{tabular}

Nilai TTF untuk sub-sistem BRV20, dinyatakan pada Tabel 3.

Tabel 3. Waktu kegagalan sub-sistem electric power supply BRV20 Teras 53-88

\begin{tabular}{|c|c|c|}
\hline $\begin{array}{c}\text { Teras } \\
\text { Nomor }\end{array}$ & Waktu Kegagalan & $\begin{array}{c}\text { TTF } \\
\text { (hari) }\end{array}$ \\
\hline 59 & $2006-12-14$ & 0 \\
\hline 62 & $2007-10-21$ & 311 \\
\hline 62 & $2007-12-09$ & 49 \\
\hline 63 & $2008-01-16$ & 38 \\
\hline 66 & $2008-11-29$ & 318 \\
\hline 69 & $2009-11-10$ & 346 \\
\hline 69 & $2009-11-16$ & 6 \\
\hline 80 & $2012-11-02$ & 1082 \\
\hline 83 & $2013-06-28$ & 238 \\
\hline 86 & $2014-12-03$ & 523 \\
\hline 87 & $2015-03-26$ & 113 \\
\hline
\end{tabular}

Nilai TTF untuk sub-sistem BRV30, dinyatakan pada Tabel 4.

Tabel 4. Waktu kegagalan sub-sistem electric power supply BRV30 Teras 53-88

\begin{tabular}{|c|c|c|}
\hline $\begin{array}{c}\text { Teras } \\
\text { Nomor }\end{array}$ & $\begin{array}{c}\text { Waktu } \\
\text { Kegagalan }\end{array}$ & $\begin{array}{c}\text { TTF } \\
\text { (hari) }\end{array}$ \\
\hline 53 & $2005-05-23$ & 0 \\
\hline 56 & $2006-04-02$ & 314 \\
\hline 57 & $2006-04-14$ & 12 \\
\hline 57 & $2006-04-25$ & 11 \\
\hline 60 & $2007-04-22$ & 362 \\
\hline 66 & $2008-12-01$ & 589 \\
\hline 69 & $2009-02-12$ & 662 \\
\hline 69 & $2009-11-16$ & 350 \\
\hline 82 & $2013-04-11$ & 1519 \\
\hline
\end{tabular}

Nilai $\quad$ TTF $\quad$ sub-sistem $\quad$ BNC01 dinyatakan pada Tabel 5.
Tabel 5. Waktu kegagalan sub-sistem electric power supply BNC01Teras 53-88

Uji kesesuaian terbaik (goodness of fit) dilakukan untuk sub-sistem kelompok electric power supply yaitu BRV10, BRV20, BRV30, dan BNC01 masing-masing terhadap sebaran weibull menggunakan analisis keandalan yang dinyatakan dalam Distribution Overview Plot. Diperoleh nilai Anderson Darling masing-masing 1,875; 1,$468 ; 1,990$ dan 3,806, sebagaimana ditampilkan pada Gambar 2.

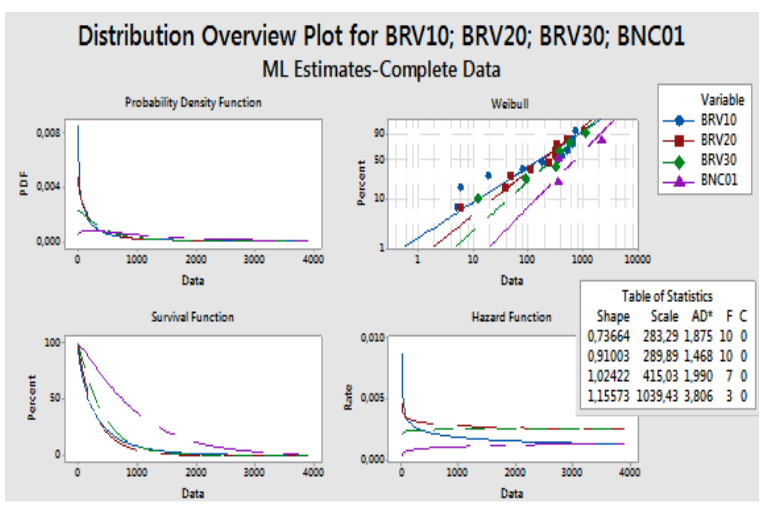

Gambar 2. Weibull distribution overview plot BRV10, BRV20, BRV30 dan BNC01

Uji kesesuaian terbaik untuk sub-sistem BRV10, BRV20, BRV30, dan BNC01 terhadap sebaran normal dinyatakan pada Gambar 3. Diperoleh nilai Anderson Darling berturut-turut 1,$815 ; 1,870 ; 2.121$ dan 3,875. 


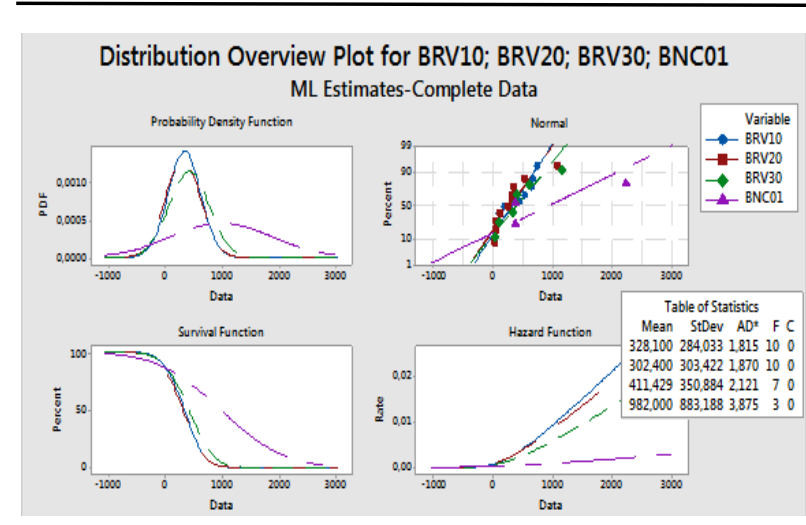

Gambar 3. Normal distribution overview plot BRV10, BRV20, BRV30 dan BNC01

Uji kesesuaian terbaik untuk BRV10, BRV20, BRV30, dan BNC01 terhadap sebaran eksponensial dinyatakan pada Gambar 4. Diperoleh nilai Anderson Darling berturut-turut 2,332; 1,476; 1,996 dan 3,756.

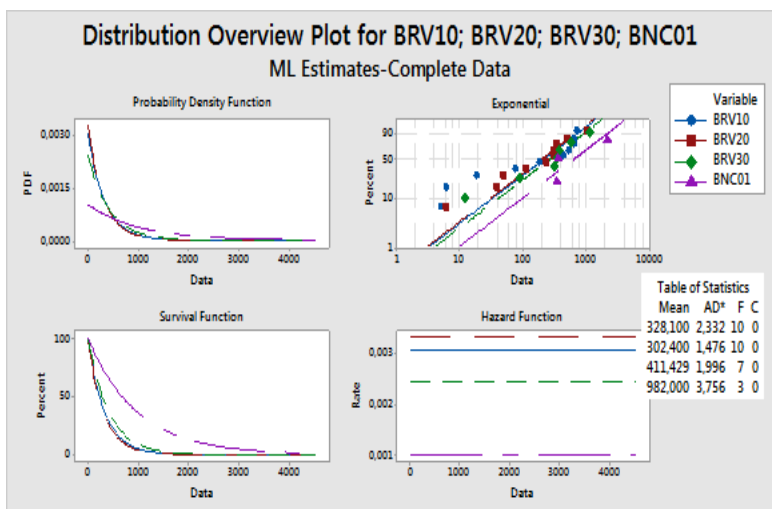

Gambar 4. Eksponensial distribution overview plot BRV10, BRV20, BRV30 dan BNC01

Uji kesesuaian terbaik untuk BRV10, BRV20, BRV30, dan BNC01 terhadap sebaran lognormal dinyatakan pada Gambar 5. Diperoleh nilai Anderson Darling berturutturut 1,$922 ; 1,608 ; 2,147$ dan 3,868.

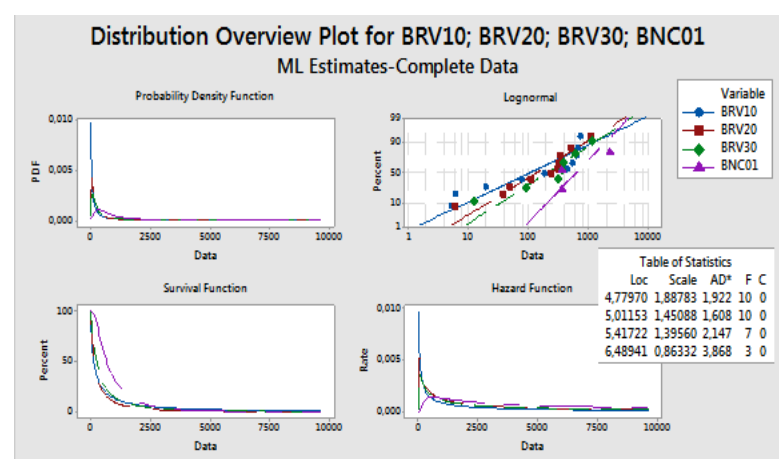

Gambar 5. Lognormal Distribution overview plot BRV10, BRV20, BRV30 dan BNC01

Dari uji kesesuaian empat sebaran yang dilakukan untuk BRV10 diperoleh mengikuti sebaran normal yang dinyatakan dengan nilai Anderson Darling terkecil 1.815 dengan nilai rata-rata 328,1 hari. Waktu rata-rata kegagalan untuk sub-sistem BRV10 diperoleh 328 hari. Interval perawatan untuk BRV10 dilakukan 6 bulan sekali atau 180 hari. Terjadinya kegagalan lebih lama dari interval perawatan yang ditetapkan. Dengan demikian, sub-sistem electric power supply BRV10 masih dalam keadaan baik atau andal.

Uji kesesuaian untuk BRV20 diperoleh mengikuti sebaran weibull yang dinyatakan dengan nilai Anderson Darling terkecil 1.468 dengan nilai scale 289,89 hari. Waktu ratarata kegagalan untuk sub-sistem BRV20 diperoleh 289 hari. Interval perawatan untuk BRV20 dilakukan 6 bulan sekali atau 180 hari. Terjadinya kegagalan lebih lama dari interval perawatan yang ditetapkan. Artinya, sub-sistem electric power supply BRV20 juga masih berada dalam keadaan baik.

Kemudian, uji kesesuaian untuk BRV30 diperoleh mengikuti sebaran weibul 


\begin{tabular}{|c|c|c|}
\hline $\begin{array}{c}\text { Teras } \\
\text { Nomor }\end{array}$ & Waktu Kegagalan & $\begin{array}{c}\text { TTF } \\
\text { (hari) }\end{array}$ \\
\hline 55 & $18 / 11 / 2005$ & 0 \\
\hline 56 & $12 / 03 / 2006$ & 114 \\
\hline 65 & $20 / 08 / 2008$ & 892 \\
\hline 66 & $11 / 12 / 2008$ & 113 \\
\hline 68 & $30 / 6 / 2009$ & 201 \\
\hline 70 & $23 / 01 / 2010$ & 207 \\
\hline 74 & $21 / 03 / 2011$ & 422 \\
\hline 80 & $04 / 10 / 2012$ & 563 \\
\hline 84 & $17 / 12 / 2013$ & 439 \\
\hline
\end{tabular}

yang dinyatakan dengan nilai Anderson

Darling terkecil 1.990 dan nilai scale 415,03 hari. Waktu rata-rata kegagalan untuk subsistem BRV30 diperoleh sebesar 415 hari. Interval perawatan untuk BRV30 dilakukan 6 bulan sekali atau 180 hari, yang berarti kegagalan lebih lama dari interval perawatan yang ditetapkan. Sub-sistem electric power supply BRV30 pun berada dalam keadaan baik.

Uji kesesuaian untuk BNC01 diperoleh mengikuti sebaran eksponensial yang dinyatakan dengan nilai Anderson Darling (AD) terkecil 3,756 dengan nilai scale atau rata-rata 982,00. Waktu rata-rata kegagalan untuk sub-sistem BNC01 diperoleh 982 hari. Interval perawatan untuk BNC01 dilakukan 6 bulan sekali atau 180 hari. Terjadinya kegagalan lebih lama dari interval perawatan yang ditetapkan. Artinya, sub-sistem electric power supply BNC01 juga masih dalam keadaan baik.

Selisih waktu kegagalan antara kegagalan sebelumnya dengan berikutnya (TTF) untuk sub-sistem instrument control cabinet CRB01 dinyatakan pada Tabel 6 .
Tabel 6. Waktu kegagalan sub-sistem instrument control cabinet CRB01 Teras 53-88

Nilai TTF sub-sistem instrument control cabinet CRB03 dinyatakan pada Tabel 7.

Tabel 7. Waktu kegagalan sub-sistem instrument control cabinet CRB03 Teras 53-88

\begin{tabular}{|c|c|c|}
\hline $\begin{array}{c}\text { Teras } \\
\text { Nomor }\end{array}$ & Waktu Kegagalan & $\begin{array}{c}\text { TTF } \\
\text { (hari) }\end{array}$ \\
\hline 54 & $18 / 11 / 2005$ & 0 \\
\hline 66 & $02 / 02 / 2009$ & 1172 \\
\hline 80 & $24 / 10 / 2012$ & 1360 \\
\hline 83 & $15 / 07 / 2013$ & 264 \\
\hline
\end{tabular}

Uji kesuaian dilakukan untuk subsistem instrument control cabinet CRB01 dan CRB03 terhadap Sebaran Weibull yang dinyatakan pada Gambar 6.

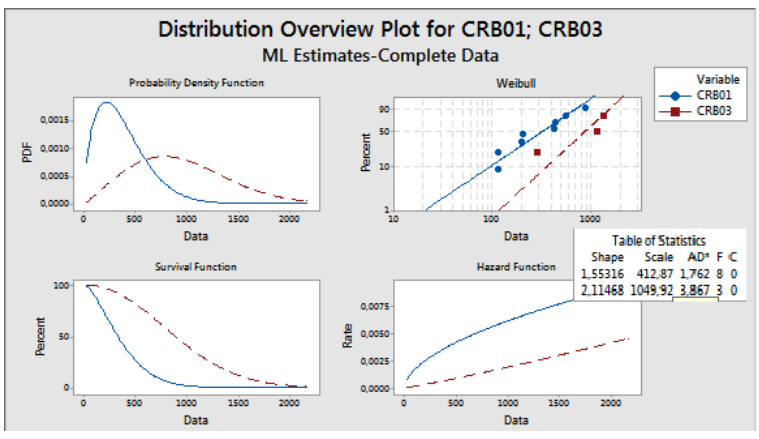

Gambar 6. Distribution overview plot sebaran weibull untuk CRB01 dan CRB03

Diperoleh nilai Anderson-Darling untuk CRB01 dan CRB03 adalah 1,762 dan 3,867. Uji kesuaian sub-sistem CRB01 dan CRB03 terhadap sebaran normal dinyatakan pada Gambar 7. 
Gambar 7. Distribution overview plot sebaran normal untuk CRB01, CRB03

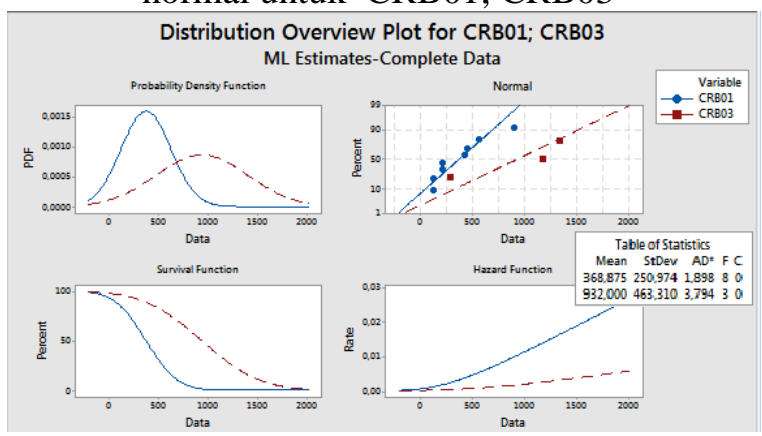

Dari sini, diperoleh nilai Anderson Darling untuk kedua sub-sistem tersebut berturut-turut sebesar 1,898 dan 3,794.

Uji kesuaian dilakukan untuk subsistem CRB01 dan CRB03 terhadap Sebaran Eksponensial dinyatakan pada Gambar 8. Diperoleh nilai Anderson-Darling untuk kedua sub-sistem masing-masing adalah 2,002 dan 3,871 .

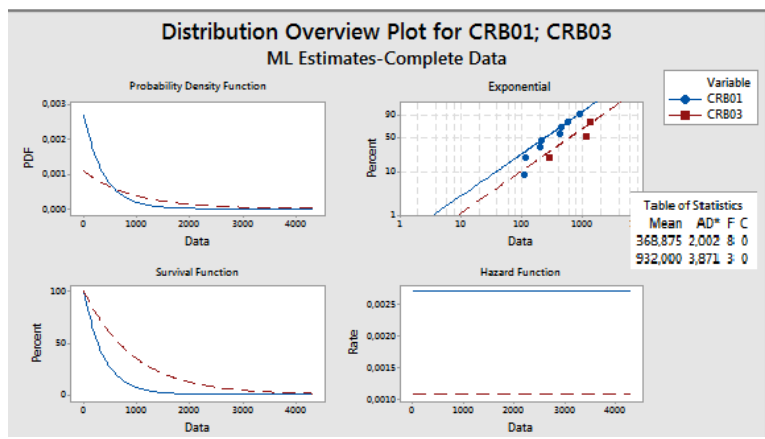

Gambar 8. Distribution overview plot eksponensial untuk CRB01 dan CRB03

Uji kesuaian dilakukan untuk subsistem CRB01 dan CRB03 terhadap Sebaran Lognormal dinyatakan pada Gambar 9. Diperoleh nilai Anderson Darling untuk kedua sub-sistem berturut-turut sebesar 1,800 dan 3,854 .

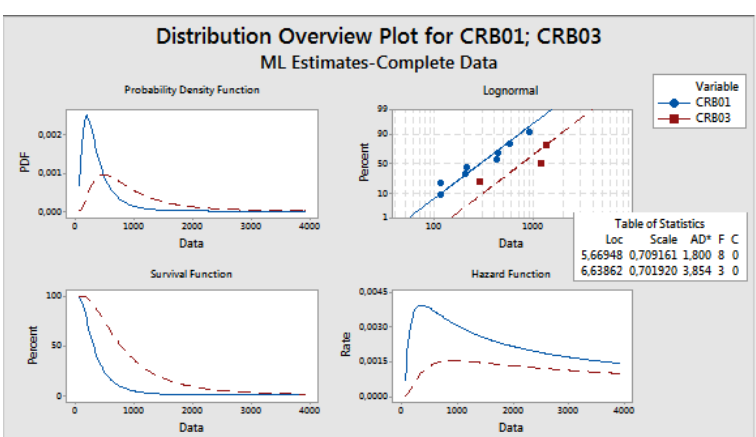

Gambar 9. Distribution overview plot sebaran lognormal untuk CRB01 dan CRB03

Dari uji kesesuaian sub-sistem CRB01, untuk sebaran yang sesuai adalah Sebaran Weibull dengan nilai Anderson Darling terkecil 1,762 dan scale (waktu rata-rata kegagalan) 412,87 atau 412 hari. Interval perawatan untuk CRB01 dilakukan 6 bulan (180 hari) sekali. Terjadinya kegagalan lebih lama dari interval perawatan yang ditetapkan. Dengan demikian, sub-sistem CRB01 masih dalam keadaan andal.

Untuk uji kesesuaian sub-sistem CRB03 diperoleh sebaran sesuai adalah Sebaran Normal, dengan nilai Anderson Darling terkecil 3,794 dan waktu rata-rata kegagalan 932 hari. Interval perawatan untuk CRB03 dilakukan 6 bulan (180 hari). Terjadinya kegagalan lebih lama dari interval perawatan yang ditetapkan. Sebagaimana sub-sistem sebelumnya, sub-sistem CRB03 juga masih berada dalam keadaan baik.

\section{KESIMPULAN}

Analisis keandalan telah dilakukan pada sistem instrumentasi dan elektrik RSGGAS dan diperoleh karakteristik parameter waktu kegagalan beberapa sub-sistem yang 
mengalami kegagalan dalam kurun waktu tahun 2005-2015. Diperoleh sebaran waktu kegagalan yang termasuk kelompok subsistem electric power supply yaitu BRV10, BRV20, BRV30, dan BNC01 dengan masing masing nilai rata-rata waktu kegagalan lebih lama dari interval perawatan yang ditetapkan. Demikian pula untuk sub-sistem instrument control cabinet CRB01 dan CRB03 mempunyai nilai rata-rata waktu kegagalan lebih lama dari interval perawatan yang telah ditetapkan. Karena itu, dapat dikatakanbahwa sub-sistem instrumentasi dan elektrik secara umum masih dalam keadaan andal.

\section{UCAPAN TERIMAKASIH}

Penulis mengucapkan terimakasih atas dukungan anggaran DIPA tahun 2019 di PTKRN sehingga terlaksananya kegiatan penelitian ini.

\section{DAFTAR PUSTAKA}

1. M. SUSMIKANTI, A. SAEPUDIN, DESWANDRI "Database System Development for Component Reliability of RSG-GAS Based on Web," pp. 97-104, 2016.

2. M. SUSMIKANTI, A. SAEPUDIN, A. SOULISA, M. SUBEKTI, AND G. R. SUNARYO, "Database System Development for Operational Parameter of RSG-GAS based on web," pp. 39-48, 2017.
3. M. SUSMIKANTI, E. HARTINI, A. SAEPUDIN, AND J. B. SULISTYO, "Jurnal Pengembangan Energi Nuklir Component Analysis of Purification System of RSG-GAS," vol. 20, no. 1, pp. 31-39, 2018.

4. Unit Jaminan Mutu RSG-GAS, “Klasifikasi Peralatan /Kkomponen RSG-GAS."

5. Unit Jaminan Mutu RSG-GAS, “Perbaikan Teras 53-88 Laporan Operasi RSG-GAS," no. 1, 2005.

6. Unit Jaminan Mutu RSG-GAS, “PerawatanTeras 53-88, Laporan Operasi RSG-GAS," no. april, 2005, pp. 9-25.

7. T. KIM, "Safety Classification of Systems, Structures, and Components for Pool-Type Research Reactors," Nucl. Eng. Technol., vol. 48, no. 4, pp. 1015-1021, 2016.

8. R. Krivanek and R. Havel, "Long term operation of nuclear power plants IAEA SALTO missions observations and trends," Nucl. Eng. Des., vol. 305, pp. 64-67, 2016.

9. K. C. DATSIOU AND M. OVEREND, "Weibull parameter estimation and goodness-of-fit for glass strength data," Struct. Saf., vol. 73, pp. 29-41, 2018.

10. J. WANG, S. QIN, S. JIN, AND J. WU, 
"Estimation methods review and analysis of offshore extreme wind speeds and wind energy resources," Renew. Sustain. Energy Rev., vol. 42, pp. 26-42, 2015.

11. I. POBOČíKOVÁ AND M. MICHALKOVÁ, "Application of four probability distributions for wind speed modeling," vol. 192, pp. 713718, 2017.

12. F. FARIDAFSHIN, B. GRECHUK, AND A. NAESS, "Calculating exceedance probabilities using a distributionally robust method," Struct. Saf., vol. 67, pp. 132-141, 2017.

13. H. ZHANG, Y. YU, AND Z. LIU, "Study on the Maximum Entropy Principle applied to the annual wind speed probability distribution : A case study for observations of intertidal zone anemometer towers of Rudong in East China Sea," Appl. Energy, vol. 114, pp. 931-938, 2014. 